\title{
AUTOMATIC INFORMATION EXCHANGE AS A MULTILATERAL SOLUTION TO TAX HAVENS
}

\author{
Tyler J. Winkleman*
}

"In theoretical physics, dark matter is the stuff in the universe that we can identify only by its gravitational pull. [In theoretical economics], dark matter is foreign wealth, the existence of which we can infer from the income it provides." On April 9, 1998, the Organization for Economic Cooperation and Development (OECD) issued a report spotlighting countries that facilitate the accumulation of dark matter. ${ }^{2}$ Generally referred to as "tax havens," these countries are problematic not only to economists, who are forced to infer the amount of wealth held within their jurisdictions, but also to the international community; tax havens facilitate tax avoidance, tax evasion, and criminal activity, such as money laundering and embezzlement. ${ }^{4}$

Tax avoidance and tax evasion jeopardize government revenues worldwide. ${ }^{5}$ U.S. revenue losses have been estimated at $\$ 100$ billion a year, and many European countries suffer losses exceeding billions of euros. ${ }^{6}$ "Individually tax havens may appear small and insignificant, but in combination they play an important role in the world economy."7 This is especially true in the financial services industry, ${ }^{8}$ where the use of tax havens is particularly relevant. ${ }^{9}$ Because all industries utilize banks and insurance companies, the scope of the financial services industry and the resulting influence of tax havens on the global economy are particularly broad. ${ }^{10}$ For example, offshore entities were integral to the Enron and Bayou Management

* J.D. Candidate, 2012, Indiana University Robert H. McKinney School of Law; B.S., 2008, Grace College, Winona Lake, Indiana. The author would like to thank his wife, Erin, for her support and patience; his family for their feedback and encouragement; and Professor Peter A. Prescott for lending his expertise in international tax law and for his advice at the outset of this project.

1. America's Dark Materials, THE ECONOMIST (Jan. 19, 2006), http:// www.economist.com/node/5408129.

2. ORG. FOR ECON. CO-OPERATION \& DEV., HARMFUL TAX COMPETITION: AN EMERGING GLOBAL IsSUE, (1998), http://www.oecd.org/dataoecd/33/0/1904176.pdf [hereinafter OECD].

3. Ronen Palan et al., TaX Havens: How Globallzation Really Works 238 (Eric Helleiner \& Jonathan Kirshner eds., 2010).

4. Id.

5. Background Info. for Press Briefing, OECD, Promoting Transparency and Exchange of Information for Tax Purposes, para. 1 (Jan. 19, 2010), available at http://www.oecd.org/ dataoecd/26/28/44431965.pdf.

6. Id.

7. PALAN ET AL., supra note 3, at 3.

8. See Lynnley Browning, An Offshore Spotlight for Madoff, N.Y. TIMES, Dec. 31, 2008, at B1.

9. Id.

10. Id. 
investment scandals in 2001 and 2005, respectively. ${ }^{11}$

While the OECD's report was issued over a decade ago, it has regained relevancy since the organization's "campaign to regulate international tax competition" failed in 2002. "The near-collapse of the West's banking industry [in 2008] has drastically increased governments' need to raise funds, brutally exposed the risks inherent in small countries with large financial sectors, and raised questions about the role of offshore centres in destabilizing the [economic] system." ${ }^{, 13}$ Tax havens are once again under heavy attack, ${ }^{14}$ and the OECD's report listed four key factors to help identify such harmful, preferential regimes. ${ }^{15}$ This Note focuses on two of the four listed factors-lack of regime transparency and ineffective exchange of tax information. Specifically, this Note explores how effective exchange of information can remedy the lack of transparency problem.

Part I of this Note analyzes tax havens, their characteristics and controversial nature, and how they became the subject of international scrutiny. This Part first addresses the difficulty in defining tax havens and discusses their typical characteristics; ${ }^{16}$ it then examines statistics about the relevance of tax havens with regard to the assets held within their jurisdictions. ${ }^{17}$ Next, this Part chronicles the steps taken by the international community in response to the continual shift of assets into tax haven jurisdictions. ${ }^{18}$ Finally, it discusses sovereignty, the influence of sovereignty on tax related matters, and why tax solutions should not implicate nations' sovereign rights. ${ }^{19}$

Part II examines the steps taken by the OECD to support regime transparency and the effective exchange of tax information among nations. This Part first provides a brief history of the OECD's campaign against harmful, preferential tax regimes ${ }^{20}$ and then highlights the primary strength of the OECD's initiative-its inclusive definition of key terms. ${ }^{21}$ Finally, this Part discusses the weaknesses of the OECD's initiative, highlighting its failures to be truly multilateral and to require automatic exchange of information. ${ }^{22}$

Part III examines the steps taken by the European Union (EU) to support transparency and the effective exchange of information. This Part highlights the primary strengths of the EU's initiative, which are its call for automatic

11. Id.

12. J. C. Sharman, Havens in a Storm: The Struggle for Global TaX Regulation 1 (Peter J. Katzenstein ed., 2006).

13. Vanessa Houlder, Harbours of Resentment, Fin. TiMES, Dec. 1, 2008, at 11.

14. Id.

15. See infra Part I.A.

16. See infra Part I.A.

17. See infra Part I.B.

18. See infra Part I.C.

19. See infra Part I.D.

20. See infra Part II.

21. See infra Part II.A.

22. See infra Part II.B. 
exchange of information and its multilateral nature. ${ }^{23}$ This Part also discusses the initiative's weaknesses, including the under-inclusiveness of its key defined terms and its allowance of a withholding tax in lieu of automatic information exchange. ${ }^{24}$

Part IV offers a comparative analysis of the actions taken by the OECD and the $\mathrm{EU}^{25}$ and proposes a hybrid approach for eradicating harmful, preferential tax regimes. ${ }^{26}$ Part $\mathrm{V}$ addresses the political challenges of enacting such an approach, primarily, a requisite change in existing domestic secrecy laws. ${ }^{27}$ It also discusses how the unrest in the Middle East may serve as a conduit to effectuating change in secrecy laws internationally $y^{28}$ and how Ireland is primed to serve as an effective leader of that change ${ }^{29}$ Ultimately, this Note proposes that, in the wake of the worldwide financial crisis, there exists a window of political opportunity, which countries implementing austerity measures should seize in order to unite developed countries and tax havens in implementing a multilateral, mutually beneficial solution. ${ }^{30}$

\section{TAX HaVens}

It is important to recognize that there are no hard and fast rules regarding what constitutes a "tax haven." The term "lacks a clear definition, and its application is often controversial and contested."32 Individual organizations have opted to categorize tax havens using different criteria, ${ }^{33}$ resulting in varying lists that range from twenty to one hundred countries. ${ }^{34}$ This Note utilizes the OECD's categorization. ${ }^{35}$

\section{A. What is a Tax Haven?}

The OECD categorizes tax havens according to four key factors: (1) "[n]o or low effective tax rates,",36 (2) "“[r]ing-fencing' of regimes," ${ }^{, 37}$ (3) "[l]ack of

23. See infra Part III.A.

24. See infra Part III.B.

25. See infra Part IV.A.

26. See infra Part IV.B.

27. See infra Part V.

28. See infra Part V.A.

29. See infra Part V.B.

30. See infra Part V.C.

31. See SHARMAN, supra note 12, at 21.

32. Id.

33. See id.

34. Id.

35. OECD, supra note 2, paras. 61-64.

36. Id. para. 61. "A low or zero effective tax rate on the relevant income is a necessary starting point for an examination of whether a preferential tax regime is harmful. A zero or low effective tax rate may arise because the schedule rate itself is very low or because of the way in which a country defines the tax base to which the rate is applied. A harmful preferential tax 
transparency,"38 and (4) "[1] ack of effective exchange of information." ${ }^{, 39} \mathrm{~A}$ tax haven is identified by the requisite presence of the first factor, together with one or more of the remaining three, ${ }^{40}$ and in June 2000 , thirty-five jurisdictions qualified as tax havens under this analysis. ${ }^{41}$

There are generally three types of tax haven regimes: pure tax havens, liberal tax havens, and tax treaty havens. ${ }^{42}$ Pure tax havens "have no direct taxes on income, profits or capital gains, death duties, succession taxes or gift and estate taxes. ${ }^{\not 3}$ Rather, they may levy employment, customs, duty, or real property taxes as well as corporate licensing or registration fees. ${ }^{44}$ Liberal tax havens "tax income from domestic sources but exempt all income from foreign sources. [Thus, a] company incorporated in one of these havens can earn unlimited amounts of foreign source income without paying any local income tax." 45 Tax treaty havens are "parties to tax treaties under which they offer access to attractive markets to individuals and corporations who are not residents of the tax havens. ${ }^{, 46}$ All three types of havens can be used to facilitate tax evasion or tax avoidance. ${ }^{47}$

regime will be characterised by a combination of a low or zero effective tax rate and one or more [of the] other factors ...." Id. at 27, Box II.

37. Id. para. 62. "Some preferential tax regimes are partly or fully insulated from the domestic markets of the country providing the regime. The fact that a country feels the need to protect its own economy from the regime by ring-fencing provides a strong indication that a regime has the potential to create harmful spillover effects. Ring-fencing may take a number of forms, including: a regime may explicitly or implicitly exclude resident tax payers from taking advantage of its benefits"; or "enterprises which benefit from the regime may be explicitly or implicitly prohibited from operating in the domestic market." Id. at 27, Box II.

38. Id. para. 63. "The lack of transparency in the operation of a regime will make it harder for the home country to take defensive measures. Non-transparency may arise from the way in which a regime is designed and administered. Non-transparency is a broad concept that includes, among others, favourable application of the laws and regulations, negotiable tax provisions, and a failure to make widely available administrative practices." Id. at 27, Box II.

39. Id. para. 64. "The lack of effective exchange of information in relation to taxpayers benefiting from the operation of a preferential tax regime is a strong indication that a country is engaging in harmful tax competition." Id. at 27, Box II.

40. Id. para. 61 .

41. OECD, TOWARDS Global TAX CO-OPERATION, at 17, (2000), http://www.oecd.org/ dataoecd/25/27/44430257.pdf [hereinafter GlOBAL TAX Co-OPERATION]. The thirty-five jurisdictions were: Andorra, Anguilla, Antigua and Barbuda, Aruba, the Bahamas, Bahrain, Barbados, Belize, British Virgin Islands, Cook Islands, Dominica, Gibraltar, Grenada, Guernsey, Isle of Man, Jersey, Liberia, Liechtenstein, Maldives, Marshall Islands, Monaco, Montserrat, Nauru, Netherlands Antilles, Niue, Panama, Samoa, Seychelles, St. Lucia, St. Christopher and Nevis, St. Vincent and the Grenadines, Tonga, Turks and Caicos, U.S. Virgin Islands, and Vanuatu. Id.

42. Charles R. Irish, Tax Havens, 15 VAND. J. TRanSNaT'L L. 449, 452 (1982).

43. Vincent P. Belotsky, Jr., The Prevention of Tax Havens via Income Tax Treaties, 17 CAL. W. INT'L L.J. 43, 53 (1987).

44. Id.

45. Id. at 54 .

46. Id.

47. Id. at 50 . 


\section{B. Why are Tax Havens Controversial?}

The fact that the term "tax haven" lacks a clear definition has allowed harmful, preferential tax regimes to argue:

1. They are not tax havens;

2. It is not their fault that other parties use them as tax havens;

3. They are doing their best to cooperate with other countries to root out abuse; and

4. They are highly regulated economies. ${ }^{48}$

Understandably, nations whose taxes are being unlawfully evaded via tax havens view these contentions as controversial, and this controversy is amplified by the magnitude of wealth held offshore. ${ }^{49}$ It has been estimated that $\$ 11.5$ trillion of assets are held offshore and that the tax not paid on these assets exceeds $\$ 255$ billion. ${ }^{50}$

"Statistics about tax havens are notoriously confusing" and vary significantly across the spectrum of tax haven definitions. ${ }^{51}$ Moreover, data on offshore finance is often dramatically incomplete. ${ }^{52}$ The Cayman Islands, for example, "does not report dollar amounts on nonbank activity," leaving its "huge investment and hedge fund industry off the official radar." Despite such gaps, the Bank for International Settlements (BIS) has established itself as an abundant and growing source of offshore financial services information. ${ }^{54}$

BIS is a bank-controlled institution that records bank deposits by country. ${ }^{55}$ According to its estimate in June 2004, offshore bank deposits total $\$ 2.7$ trillion, nearly twenty percent of the $\$ 14.4$ trillion in total bank deposits. ${ }^{56}$ Notably, the BIS estimate includes only cash deposits, ${ }^{57}$ meaning the $\$ 2.7$ trillion does not reflect financial assets such as stocks, bonds, real estate, and interests held in private companies. ${ }^{58}$ Applying a 3.5 ratio $^{59}$ of cash to total

48. PALAN ET AL., supra note 3, at 237.

49. Id. at 237-38. For the purposes of this Note, "offshore" means "legal space that decouples the real and the legal location of a transaction with an aim to avoid some or all kind of regulation (tax regulation, financial regulation, etc.)." Id. at 250.

50. Richard Murphy, Tax Research LLP, The Price of Offshore, TAX JUST. NETwORK (2005), http://www.taxjustice.net/cms/upload/pdf/Briefing_Paper_-_The_Price_of_Offshore _14_MAR_2005.pdf.

51. PALAN ET AL., supra note 3, at 46.

52. Martin A. Sullivan, Tax Analysts Offshore Project, 117 TAX NotES 87, 87 (2007).

53. Id.

54. Id.

55. Murphy, supra note 50. More information on the BIS is available at the organization's website, http://www.bis.org.

56. Id. (citing data confirmed by the BIS on January 3,2005 ).

57. Id.

58. Id. 
financial assets to the cash deposits reported by BIS "yields a figure for total financial assets held offshore amounting to $\$ 9.45$ trillion." accounting for assets that are harder to value, such as real estate, the estimated value of assets held offshore begins to approach $\$ 12$ trillion. ${ }^{61}$

\section{How Did Tax Havens Become Subjected to International Scrutiny?}

In May 1996 the heads of state of the G7 nations met in Lyon, France, ${ }^{62}$ where they "called upon the OECD to 'develop measures to counter the distorting effects of harmful tax competition on investment and financing decisions and the consequences for national tax bases ... .",63 The OECD reported back in 1998, issuing Harmful Tax Competition: An Emerging Global Issue. ${ }^{64}$ The organization also established the Forum on Harmful Tax Practices, ${ }^{65}$ which subsequently compiled a list of thirty-five jurisdictions deemed to be tax havens. ${ }^{66}$ Further, the OECD recommended that its members implement a number of defensive measures against tax havens unwilling to cooperate with the OECD initiative. ${ }^{67}$

The alleged "tax havens" responded obstinately to the OECD's efforts. Their protests "included promises to not sign up for the initiative, publically challenging the OECD, and bilateral lobbying to more sympathetic OECD states." ${ }^{68}$ These efforts helped soften the blow of the OECD initiative, which was further weakened by U.S. Treasury Secretary Paul O'Neill's criticism in a May 10, 2001 press release. ${ }^{69}$ In relevant part, he stated:

[T] he underlying premise that low tax rates are somehow suspect and... the notion that any country, or group of countries, should interfere in any other country's decision about how to structure its own tax system [is troubling] .... [Consequently,] [t]he work of this particular OECD initiative . . . must be

59. When examining the typical composition of net worth, "[t]he ratio of cash to total financial assets ... [ranges from] 3.3 to 3.85 ." Id.

60. Id.

61. Id.

62. The Group of Seven that met at the 1996 Lyon Summit included: Canada, France, Germany, Italy, Japan, the United Kingdom, and the United States. Doug Saunders, Weight of the World Too Heavy for these Shoulders; At This Year's G8 Summit, There's One Issue that Will Overshadow the Rest: A Growing Call for the Group's Abolition, GLOBE \& MAIL, July 5, 2008 , at $\mathrm{A} 10$.

63. OECD, supra note 2, at 3, 7 (quoting OECD Ministerial Communiqué, May 1996).

64. See id. at 3. All but two OECD member nations approved the report; Luxembourg and Switzerland abstained. $I d$. at 73-78, Annex II.

65. Global TAX Co-OPERATION, supra note 41 , para. 1 , at 8 .

66. Id. para. 17 , at 17 (listing the thirty-five tax haven jurisdictions).

67. Id. para. 35 , at 25.

68. Martin A. Sullivan, Lessons from the Last War on Tax Havens, 116 TAX NOTES 327, 328 (2007) [hereinafter Lessons].

69. See Press Release, U.S. Dep't of the Treasury, Statement of Treasury Secretary Paul O'Neill on OECD Tax Havens Project, PO-366 (May 10, 2001), available at http://www.treasury.gov/press-center/press-releases/Pages/po366.aspx. 
refocused on the core element that is our common goal: the need for countries to be able to obtain specific information from other countries upon request in order to prevent the illegal evasion of their tax laws by the dishonest few. In its current form, the project is too broad .... ${ }^{70}$

\section{Sovereignty}

According to Treasury Secretary O'Neill, the OECD initiative had become too broad, in large part, because it was infringing on nations' sovereign rights. ${ }^{71}$ Foundationally, "sovereignty" is defined by the existence of territory, people, and government, ${ }^{72}$ and "[i]n possessing these elements, a sovereign state should display internal control and supremacy, along with external independence from other states." control over tax policy choices - they are influenced and constrained by the political economy within their own domestic system ... and by the need to account for the implications of their tax rules globally .....74

The issue of sovereignty weighs heavily on states considering international tax cooperation, ${ }^{75}$ as it should: "the lack of absolute control does not render a state's interest in maintaining substantial control an implausible or irrational position ... [and] an expression of interest in retaining more control over tax policy does not translate into a blanket unwillingness to cooperate." ${ }^{.76} \mathrm{It}$ is therefore problematic that, of the four factors set forth by the OECD, only the existence of "low or no effective tax rates" is required to constitute a tax haven. ${ }^{77}$ While tax rates may seem to be a logical starting point, "countries are highly reluctant to give up their right to set generally acceptable tax rates, because that right is a core attribute of sovereignty.",78

Choice of tax rate implicates sovereignty on two fundamental issues, revenue and fiscal policy control. "Taxes are necessary to raise revenue for public goods and infrastructure, as well as to provide other sorts of public

70. Id.

71. Id.

72. Diane Ring, Democracy, Sovereignty and Tax Competition: The Role of Tax Sovereignty in Shaping Tax Cooperation, 9 FLA. TAX REV. 555, 557 (2009).

73. Id.

74. Id. at 559 .

75. Diane M. Ring, What's at Stake in the Sovereignty Debate?: International Tax and the Nation-State, 49 VA. J. INT'L L. 155, 167 (2008) [hereinafter What's at Stake].

76. Ring, supra note 72 , at 559-60.

77. OECD, supra note 2, para. 61 , at 26 .

78. Reuven S. Avi-Yonah, Globalization, Tax Competition, and the Fiscal Crisis of the Welfare State, 113 HARV. L. REV. 1573, 1629 (2000).

79. What's at Stake, supra note 75, at 167. 
services conducive to general welfare and economic growth." ${ }^{" 80}$ Concurrently, "'[a]ny tax that produces revenue will in some way alter the social and economic order.' Taxes that only raise revenue without effecting other changes do not exist in the real world. ${ }^{, 81}$ For example, a high excise tax on tobacco not only raises revenue but also discourages smoking. ${ }^{82}$ Likewise, taxing investment income at a lower rate relative to other types of income raises revenue and encourages investing. ${ }^{83}$

In the context of tax havens, the relationship between revenue and fiscal policy "raise[s] important questions about the sovereign rights of smaller countries ... [and] about the nature of sovereignty more broadly ...."84 This is particularly true "where the rights of one state impinge, or are perceived to impinge, on the sovereign rights of other states . . . ."85 "In these cases governments may find themselves in a 'prisoners dilemma' where they collectively would be better off by not offering incentives but each feels compelled to offer the incentive to maintain a competitive business environment." ${ }^{, 86}$ If a nation's choice of tax rate merely implicated revenue, it would be difficult, at best, to achieve equilibrium among nations with differing perspectives on appropriate taxation rates. ${ }^{87}$ But because tax rate sovereignty also implicates fiscal policy control, the balancing act is next to impossible. ${ }^{88}$

Due to the sovereignty issues inherent in discussions of a nation's choice of tax rate, the solution for tax havens should be sought outside the realm of setting tax floors. For the sake of analysis, this Note accepts Treasury Secretary O'Neill's proposition that the OECD initiative had become too broad and examines information exchange among countries as a remedy to illegal tax evasion in particular jurisdictions. ${ }^{89}$

\section{THE OECD MODEL AGREEMENT}

In 2002 the OECD published the Agreement on Exchange of Information on Tax Matters (Model Agreement) for Member States to utilize in forming Tax Information Exchange Agreements (TIEAs) ${ }^{90}$ The Model Agreement serves as

80. Id. (quoting Kenneth L. Sokoloff \& Eric M. Zolt, Inequality and Taxation: Evidence from the Americas on How Inequality May Influence Tax Institutions, 59 TAX L. REV. 167, 167$68(2006))$.

81. Id. at 168 (quoting Randolph E. Paul, TAXATION FOR ProsPeriTy 214 (1st ed. 1947)).

82. Id. at 169, n.60.

83. Id. at $168-70$.

84. PALAN ET AL., supra note 3, at 238.

85. Id.

86. OECD, supra note 2, para. 80 , at 34 .

87. See What's at Stake, supra note 75 , at 167.

88. See id. at 168 .

89. Press Release, supra note 69.

90. OECD, Agreement on Exchange of Information on Tax Matters, ch. I, para. 5 (2002), available at http://www.oecd.org/dataoecd/15/43/2082215.pdf. 
a baseline for negotiations, and because the exchange of tax information can arise in both bilateral and multilateral agreements, ${ }^{91}$ it offers countries the choice of negotiating with each individual tax haven (bilateral) or with a group of tax havens (multilateral) ${ }^{92}$ Among the countries operating under the OECD guidelines in 2011, 511 maintained TIEAs. ${ }^{93}$

Aside from the transactional costs associated with negotiating either variety of TIEA, one fundamental principle becomes highly relevant in determining which type is preferable-asset shifting. Under a bilateral agreement, tax evasion will be thwarted only to the extent that tax evaders are unable to move their assets to a different tax haven. ${ }^{94}$ As long as other tax havens are willing and able to accept the assets of tax evaders located in jurisdictions party to the bilateral agreement, the assets will simply shift to another tax haven, necessitating another bilateral agreement. ${ }^{95}$ Each successive bilateral agreement likely will lead to a similar shift in assets, making tax haven status increasingly lucrative. ${ }^{96}$ Consequently, successive bilateral agreement negotiations will become more and more difficult, as the negotiating tax haven will have more to lose. ${ }^{97}$

Under a multilateral agreement, however, tax evaders will have greater difficulty finding an acceptable tax haven to accept their shifted assets because multiple jurisdictions will be parties to the same agreement. ${ }^{98}$ Even if nonparties to a multilateral agreement are willing and able to accept some assets, their ability to accommodate the glut of assets needing to be shifted will be far less likely than in a bilateral scenario. ${ }^{99}$ Therefore, multilateral negotiations are less likely to suffer from the "hold-out" problem that might result from bilateral treaty negotiations. ${ }^{100}$ While the Model Agreement includes both a "Bilateral Version" and a "Multilateral Version," 101 this Note focuses on the latter due to the fundamental advantages of multilateral negotiations.

91. OECD, Manual on Information ExChange: Module on General and Legal ASPECTS OF EXCHANGE OF INFORMATION, at 4-5 (2006), available at http://www.oecd.org/dataoecd/16/23/36647823.pdf [hereinafter MANUAL].

92. Id. at ch. I, para. 5 .

93. Tax Information Exchange Agreements (TIEAs), OECD, http://www.oecd.org/ document/7/0,3343,en_2649_33767_38312839_1_1_1_1,00.html (last visited Feb. 2, 2012) (listing TIEAs by date of signature).

94. Steven A. Dean, Philosopher Kings and International Tax: A New Approach to Tax Havens, Tax Flight, and International Tax Cooperation, 58 HASTINGS L.J. 911 , 958 (2007).

95. Id.

96. Id.

97. Id.

98. Id.

99. Id. at 959.

100. Id. at 958 .

101. MANUAL, supra note 91 , ch. II. 


\section{A. Strengths of the Model Agreement}

The Model Agreement's primary strength is that it inclusively defines the term, "person," and the types of tax to which the agreement applies. According to Article 4, "'person' includes an individual, a company and any other body of persons." 102 By using the word "includes," the scope of the Agreement extends to all organizational structures, from trusts and partnerships to collective investment schemes. ${ }^{103}$ This broad, inclusive definition of "person" prevents potential tax evaders from simply changing the form in which they hold their assets in order to circumvent the Agreement. ${ }^{104}$ Another strength is that the Model Agreement broadly "applies to taxes on income or profits, taxes on capital, taxes on net wealth, and estate, inheritance or gift taxes." ${ }^{105}$ By inclusively defining the various types of covered tax, the Agreement prevents potential tax evaders from choosing income-generating investments outside of its scope. ${ }^{106}$

\section{B. Weaknesses of the Model Agreement}

The Model Agreement's primary weaknesses are that it is not truly multilateral in nature and that it does not require automatic exchange of information. While the OECD's model TIEAs include a "Multilateral Version," ${ }^{, 107}$ the Model Agreement concedes in its introduction:

The multilateral instrument is not a "multilateral" agreement in the traditional sense. Instead, it provides the basis for an integrated bundle of bilateral treaties. A party to the multilateral Agreement would only be bound by the Agreement vis-à-vis the specific parties with which it agrees to be bound. Thus, a party wishing to be bound by the multilateral Agreement must specify in its instrument of ratification, approval or acceptance the party or parties vis-àvis which it wishes to be so bound. The Agreement then enters into force, and creates rights and obligations, only as between those parties that have mutually identified each other in their instruments of ratification, approval or acceptance that have

102. Id. ch. II, art. 4, para. 1(c) (emphasis added).

103. Id. ch. III, para. 16.

104. For example, if the term "person" is limited in scope to individuals, then an individual with a bank account in a tax haven could set up a business entity, make a capital contribution consisting of the entire balance of their existing bank account, and continue to hold assets in the tax haven in the name of the entity in order to avoid the Agreement.

105. Id. ch. III, para. 8.

106. See infra notes $136-40$ and accompanying text.

107. MANUAL, supra note 91, ch. II. 
been deposited with the depository of the Agreement. ${ }^{108}$

Thus, the OECD's "multilateral" TIEA actually serves as a "bundle of bilateral treaties," destroying the agreement's multilateral effectiveness.

Moreover, the OECD's Multilateral Version does not effectuate agreements between tax havens and developing countries. ${ }^{109}$ Since an agreement based on this version will require tax havens to agree to be specifically bound to each negotiating country, in effect, developing countries will not have sufficient leverage to strike a deal with larger countries and will likely slow the process. ${ }^{110}$ For the sake of efficiency, larger countries may instead choose to utilize the Bilateral Version, leaving developing countries without negotiating power and with no benefit from the agreement."

Another weakness of the Model Agreement is that it "only covers exchange of information upon request (i.e., when the information requested relates to a particular examination, inquiry or investigation) and does not cover automatic or spontaneous exchange of information." "12 "Automatic exchange of information ... involves the systematic and periodic transition of 'bulk' taxpayer information by the source country to the residen[t] country concerning various categories of income (e.g. dividends, interest, royalties, salaries, pensions, etc)." ${ }^{113}$ The alternative, exchange of information on request, "is a cumbersome process." 114 The requesting country must make a detailed case for the information "with the criteria set out in a lengthy legal document." example, the Bahamas-U.S. TIEA requires that

requests for tax information be in writing and contain specified details that include the name of the person, the type of information requested, the period for which the information is requested, the likely location of the information, the applicable U.S. federal tax law, whether the matter is criminal or civil in nature, and the reasons for believing that the requested information is "foreseeably relevant or material" to

108. Id. ch. I, para. 5 .

109. Tax Justice Network, Tax Information Exchange Agreements sec. 4.7 (2009), $\mathrm{http} / / / \mathrm{www}$.taxjustice.net/cms/upload/pdf/Tax_Information_Exchange_Arrangements.pdf.

110. Id. "[E]ven medium-sized developing countries like Chile, India or South Africa ... would [lack] sufficient leverage to strike a good deal with, for instance, Switzerland, on similar terms to those struck between Switzerland and the [United States] or Germany." Id.

111. Id.

112. MANUAL, supra note 91 , ch. III, para. 39.

113. OECD, Manual on INFormation Exchange: Module 3 on Automatic (or ROUTINE) EXCHANGE OF INFORMATION, at 3 (2006), available at http://www.oecd.org/ dataoecd/61/19/40502506.pdf.

114. Lessons, supra note 68, at 332.

115. Tax Justice Network, supra note 109, sec. 5.1. 
U.S. tax administration. ${ }^{116}$

"This means that the authorities requesting the information must already have a strong case even before they request the information." impossible "to follow up a suspicion without already having significant evidence." 118 Since the Multilateral Version of the Model Agreement makes automatic exchange of information optional and is not truly multilateral in nature, the steps taken by the OECD to support transparency and the effective exchange of information are less than optimal.

\section{THE EU SAVINGs DiRECTIVE}

In 2003, in response to "residents of Member States ... [being] able to avoid any form of taxation in their Member State of residence on interest they receive[d] in another Member State," 119 the Council of the EU adopted the Savings Directive "on [the] taxation of savings income in the form of interest payments." ${ }^{20}$ The Directive is multilateral, and it generally provides for the automatic exchange of information. In those Member States that opted not to participate in the automatic exchange of information-Austria, Belgium, and Luxemburg-a withholding tax is levied as an alternative. ${ }^{121}$

\section{A. Strengths of the Savings Directive}

One of the Savings Directive's primary strengths is its call for automatic exchange of information "at least once a year, within six months following the end of the tax year of the Member State of the paying agent, for all interest payments made during that year." 122 "Effective information sharing between jurisdictions ... [has] a strong deterrent effect on companies and individuals hiding assets in tax havens and [assists] tax authorities in pursuing those who evade tax." ${ }^{.23}$ In contrast, inefficient information exchange provides "ample opportunities to hinder and block requests for information ....",124 Because of the complexity of tax evasion cases, a delay in obtaining information could

116. Lessons, supra note 68, at 332.

117. Tax Justice Network, supra note 109, sec. 5.1.

118. Id.

119. Council Directive 2003/48, pmbl., para. 5, 2003 O.J. (L 157) 38 (EC) [hereinafter Savings Directive].

120. Id.

121. Id. art. 11, para. 1 ; art. 12 , para. 1.

122. Id. art. 9, para. 2.

123. Letter from Actionaid et al. to Ministers of the Council of Development and Foreign Affairs of the EU (May 20, 2010), available at http://www.eurodad.org/uploadedFiles/ CSO $\% 20$ Recommendations $\% 20$ for $\% 20$ the $\% 20$ EU\%20Council $\% 20$ Conclusions_DEV.pdf? $n=6$ 917.

124. Tax Justice Network, supra note 109, sec. 5.2 . 
extend beyond the expiration of the statute of limitations, spoiling the opportunity to litigate. ${ }^{125}$ Therefore, if the end game is preventing and prosecuting tax evaders, information exchange must be automatic and prevent obstacles to accessing relevant information.

Another strength of the Savings Directive is its truly multilateral nature. A multilateral agreement enables larger members of the EU to leverage their economic and political prowess to compensate for smaller members. ${ }^{126}$ For example, Germany, which had a Gross Domestic Product (GDP) of €2,498.8 billion in 2010, can compensate for Malta, which had a GDP of $€ 6,245.8$ million $^{127}$ and lacks the economic influence to bargain with countries in a superior negotiating position. ${ }^{128}$ Significantly, the Savings Directive issues a multilateral call for automatic exchange of information without impinging Member States' sovereign rights to set their own tax rates. ${ }^{129}$ The Savings Directive also has helped assess the interrelation of tax evasion and tax competition. Critics of the international effort to eradicate harmful, preferential tax regimes argue that it diminishes tax competition, ${ }^{130}$ but to the contrary, the Directive has diminished tax evasion while "intensifying" tax competition in the EU. ${ }^{131}$ Independent factors, such as reduced trade barriers, enhanced mobility of goods, labor, capital, and countries' inclination to seize opportunities to attract additional investment, support tax competition despite the eradication of tax havens. ${ }^{132}$

\section{B. Weaknesses of the Savings Directive}

The primary weakness of the Savings Directive is the under-inclusiveness

125. Lee A. Sheppard, Don't Ask, Don't Tell, Part 4: Ineffective Information Sharing, 122 TAX NOTES 1411,1412 (2009).

126. See Tax Justice Network, supra note 109, sec. 4.7.

127. Gross Domestic Product at Market Prices, EUROSTAT, http://epp.eurostat.ec.europa.eu/tgm/refreshTableAction.do?tab=table\&plugin=1\&init=1\&pcode $=$ tec00001\&language $=$ en (last visited Dec. 16,2011). In 2010 the Member States of the EU, in order from largest GDP to smallest, were as follows: Germany, France, United Kingdom, Italy, Spain, Netherlands, Turkey, Switzerland, Poland, Belgium, Sweden, Norway, Austria, Denmark, Finland, Portugal, Ireland, Czech Republic, Romania, Hungary, Slovakia, Croatia, Luxembourg, Slovenia, Bulgaria, Lithuania, Latvia, Cyprus, Estonia, Iceland, Macedonia, Malta. GDP statistics were unavailable for Liechtenstein, Montenegro, and Macedonia. Id.

128. See Tax Justice Network, supra note 109, sec. 4.7.

129. Unlike the OECD, whose starting point for analysis is "no or low effective tax rates," the EU's Savings Directive makes no mention of jurisdictions' effective tax rates.

130. See generally Chris EdWARDS \& DANIEL J. MITCHELL, GLOBAL TAX REVOLUTION: THE Rise of TAX COMPETITION AND THE BATtLE TO DEFEND It (2008).

131. Oleksandr Pastukhov, Counteracting Harmful Tax Competition in the European Union, 16 S.W. J. INT'L LAW 159, 165-66 (2010).

132. See id. 
of some of its key defined terms. ${ }^{133}$ Article 1 provides:

The ultimate aim of this Directive is to enable savings income in the form of interest payments made in one Member State to beneficial owners who are individuals resident for tax purposes in another Member State to be made subject to effective taxation in accordance with the laws of the latter Member State. ${ }^{134}$

Under this provision, the term, "savings income," is limited to "interest," and the term, "beneficial owner," is limited to an "individual."135

By narrowly defining "savings income" as "interest," all other forms of savings income escape the scope of the Directive. ${ }^{136}$ Common forms include dividends, capital gains, and royalties. ${ }^{137}$ Thus, by "moving [an] investment out of cash and into any other form of investment,"138 or by "[p]utting the investment in an insurance "coat' or 'wrapper,"'139 the Savings Directive becomes inapplicable. ${ }^{140}$ Since those forms of savings income are not covered by the Savings Directive, they are subject neither to the automatic exchange of information nor the withholding tax.

Likewise, by narrowly defining "beneficial owner" as an "individual," the Savings Directive becomes inapplicable to all other forms of ownership. ${ }^{141}$ Common forms of ownership include recognized business entities, such as limited liability partnerships and trusts. ${ }^{142}$ Limited liability partnerships are "tax transparent," having legal existence but no tax residence in a tax haven. ${ }^{143}$ "This allows the separation of legal ownership of assets from the location of income arising from them." ${ }^{\text {"144 }}$ By owning assets in a capacity other than as an "individual," beneficial owners will not be subject to the Savings Directive; thus, they are subject neither to the automatic exchange of information nor the withholding tax.

Another weakness of the Savings Directive is the withholding tax it imposes on countries choosing not to participate in automatic information

133. See Tax Justice Network, European Union Savings Tax Directive sec. 8.1 (2008), http://www.taxjustice.net/cms/upload/pdf/European_Union_Savings_Tax_Directive_March_08. pdf [hereinafter European Union Savings].

134. Savings Directive, supra note 119, pmbl., para. 8 (emphasis added).

135. See id.

136. European Union Savings, supra note 133, sec. 8.2.3-4.

137. Id. sec. 8.2.3.

138. Id.

139. Id. sec. 8.2.4.

140. Id. sec. 8.2 .

141. European Union Savings, supra note 133, sec. 8.2.1-2.

142. Id.

143. PALAN ET AL., supra note 3, at 88.

144. Id. 
exchange. ${ }^{145}$ The Directive requires non-participating countries to "levy a withholding tax at a rate of $15 \%$ during the first three years of the transitional period, $20 \%$ for the subsequent three years and $35 \%$ thereafter." ${ }^{\prime 14}$ Further, it directs these states to "retain $25 \%$ of their revenue and transfer $75 \%$ of the revenue to the Member State of residence of the beneficial owner of the interest." $" 147$

The withholding tax is intended to be an alternative to automatic information exchange, but in practice, it does not provide parties with a viable alternative. In 2010 the average top personal income tax rate in the EU was $37.5 \% .{ }^{148}$ Thus, even after the withholding tax increases to the Savings Directive's $35 \%$ ceiling, a Member State of residence would only receive an effective tax rate of $26.25 \%$, ${ }^{149}$ well below the EU average. By choosing the withholding tax instead of automatic information exchange Member States of residence stand to lose an average of $11.25 \%{ }^{150}$ in tax otherwise owed to them.

Moreover, since one of the primary benefits of holding assets in an outside jurisdiction is the reduction in tax liability owed to the jurisdiction of residence, intuition ${ }^{151}$ suggests that the vast majority of beneficial owners are subject to high personal income tax rates in their Member State of residence. ${ }^{152}$ As a result, beneficial owners are presumably more likely to be residents of Member States with top personal income tax rates greater than the EU average. Even at $37.5 \%$, beneficial owners stand to save $2.5 \%$ in tax by subjecting themselves to the Savings Directive's 35\% withholding tax rather than the top personal income tax rate of their Member State of residence. Depending on the amount of assets being held, $2.5 \%$ in tax savings alone could justify the use of an outside jurisdiction-and some tax evaders could save more.

For example, residents of Sweden, which imposes a top personal income

145. European Union Savings, supra note 133, sec. 3.2.

146. Savings Directive, supra note 119, art. 11, para. 1.

147. Id. art. 12, para. 1.

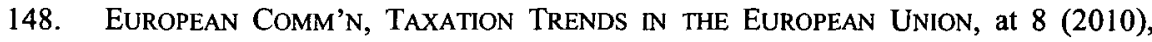
available at http://ec.europa.eu/taxation_customs/resources/documents/taxation/gen_info/ economic_analysis/tax_structures/2010/2010_main_results_en.pdf. The highest top personal income tax rate was $56 \%$ (Sweden) and the lowest was $10 \%$ (Bulgaria). Id. at 8 , Graph 3 . The countries included in the average are: Austria, Belgium, Bulgaria, Cyprus, Czech Republic, Denmark, Estonia, Finland, France, Germany, Greece, Hungary, Ireland, Italy, Latvia, Lithuania, Luxembourg, Malta, Netherlands, Poland, Portugal, Romania, Slovakia, Slovenia, Spain, Sweden and the United Kingdom. Id.

149. $35 \% \times 75 \%=26.25 \%$.

150. $37.5 \%-26.25 \%=11.25 \%$.

151. Due to a lack of transparency, information about beneficial owners as a class is largely unknown, and thus must be logically presumed or inferred. See supra notes 51-53 and accompanying text.

152. As a beneficial owner's personal income tax rate in their jurisdiction of residence lowers, so to does the beneficial owner's derived benefit from holding assets in an outside jurisdiction. 
tax rate of $56 \%,{ }^{153}$ would stand to save $21 \%{ }^{154}$ in tax on interest income by holding their assets in an outside jurisdiction. By accepting its portion of the withholding tax rather than receiving information exchanged automatically, Sweden would stand to lose $29.75 \%{ }^{155}$ in tax that would otherwise be owed. Thus, while the withholding tax may make tax evasion less attractive, tax evaders could still realize substantial tax savings by opting for the withholding tax rather than automatic information exchange.

The Savings Directive also suffers from the inability to extend to tax havens outside of the EU. ${ }^{156}$ The EU has asked Singapore, Hong Kong, Macao, Bermuda, and Barbados to participate, but thus far these countries have declined. ${ }^{157}$ As long as there are other tax havens willing and able to accept the assets of tax evaders held in jurisdictions subject to the Savings Directive, the assets will simply shift outside the reach of the EU. ${ }^{158}$ Overall, the EU's intent to support transparency and the effective exchange of information on a multilateral basis is optimal, albeit on a suboptimal scale.

\section{COMPARATIVE ANALYSIS AND RECOMMENDATION}

\section{A. Comparative Analysis}

The main similarity between the OECD initiative and the EU initiative is their acknowledgement that transparency and exchange of information are paramount to curbing tax havens. ${ }^{159}$ Their biggest difference is that the Model Agreement does not require the automatic exchange of information while the Savings Directive does. ${ }^{160}$ On the surface, this distinction may appear to be of little consequence, but its impact on the initiatives' common goals reveals the ideality of automatic information exchange.

In order for a tax-evading individual's host nation ${ }^{161}$ to request relevant information, the host nation must first know that the individual is evading taxes. ${ }^{162}$ But with the secrecy laws currently in place in many tax havens, the

153. EUROPEAN COMM'N, supra note 148, at 9. Sweden has the highest top personal income tax rate of any European Union country. See id. at 8, Graph 3.

154. $56 \%-35 \%=21 \%$.

155. $56 \%-26.25 \%=29.75 \%$.

156. See European Union Savings, supra note 133, sec. 8.2.5.

157. Id. sec. 2.4 .

158. See generally Dean, supra note 94 , at 958 .

159. Compare MANUAL, supra note 91, ch. III, para. 6, with Savings Directive, supra note 119 , paras. 14-16.

160. Compare MANUAL, supra note 91, ch. III, para. 39, with Savings Directive, supra note 119 , para. 15.

161. For the purposes of this Note, "host nation" means the tax evader's country of residence.

162. Tax Justice Network, supra note 109, sec. 5.1. 
probability of the host nation learning of the tax evasion is very remote. ${ }^{163}$ "Bank accounts in bank secrecy jurisdictions are ideal for concealment of illegally earned funds ... or [other] funds that represent unreported income in the residence country. Even if the source of funds is completely legitimate, future earnings can be concealed from the home country's taxes." ${ }^{164}$ As a result, request-based exchange of information is neither effective nor transparent. The OECD may point to the 511 TIEAs as progress, but because the TIEAs only require information exchange upon request, ${ }^{165}$ the relationship between the tax haven and the host nation has not changed in a truly meaningful way since the implementation of those agreements.

Another difference of consequence between the two initiatives is the scope of authority of the OECD and EU. Since the EU has limited reach, its ability to prevent tax evasion is minimal; evaders can simply shift their assets to a jurisdiction outside the EU's sphere of influence. ${ }^{166}$ The OECD, however, as an international body, has the influence to facilitate multilateral agreements for potentially every nation in the world while avoiding the perception of an inherent conflict of interest. Moreover, as a nongovernmental entity, the OECD can indirectly represent countries' "collective economic interest." however, directly represents the interests of only its Member States. ${ }^{168}$ Large nations such as the United States might balk at the idea of the EU leading the world in its quest to eradicate harmful preferential tax regimes, but a largely unaffiliated entity such as the OECD would allow countries to remain politically neutral should the initiative be successful.

\section{B. Recommendations}

It is this Note's recommendation that the OECD adopt a new standard modeled on the EU's Savings Directive with a few key changes. First, the new standard must have an inclusive definition of "income," including all common forms of savings income, such as interest, dividends, capital gains, and royalties. ${ }^{169}$ This will prevent tax evaders from moving their investments into forms not covered by the initiative. ${ }^{170}$ In addition, the new standard should define asset ownership to include recognized business entities, such as limited liability partnerships and trusts. ${ }^{171}$ This will prevent tax evaders from changing

163. Id. sec. 5.2 .

164. Cynthia Blum, Sharing Bank Deposit Information with Other Countries: Should Tax Compliance or Privacy Claims Prevail?, 6 FLA. TAX REV. 579, 596 (2004).

165. Tax Justice Network, supra note 109, sec. 5.1.

166. See supra notes $\mathbf{1 5 6 - 5 8}$ and accompanying text.

167. Sullivan, supra note 52, at 327.

168. Id.

169. See European Union Savings, supra note 133, sec. 8.2.3-4.

170. See id.

171. See id. sec. 8.2.1-2. 
the nature of their asset ownership to structures beyond the initiative's scope. ${ }^{172}$

Second, the OECD should eliminate the withholding tax as an alternative to automatic information exchange. ${ }^{173}$ This would ensure that assets held within any jurisdiction party to the agreement are not evading tax. ${ }^{174}$ While the withholding tax guarantees that host nations will receive some revenue from their tax evaders, ${ }^{175}$ eliminating illegal tax evasion, rather than minimizing losses, should be the initiative's goal. The withholding tax also serves as a de facto tax floor, inviting accusations that the effort is infringing on nations' sovereign rights, eliminating tax competition, and seeking tax harmonization. ${ }^{176}$

Admittedly, eliminating the withholding tax alternative would deprive tax havens of their $25 \%$ withholding tax retention, ${ }^{177}$ creating a problem for tax havens that depend on the revenue generated by offering tax haven jurisdiction. "[T]he majority of the tax havens . . . are very small jurisdictions; very few of them possess universities or research centers that teach the skills required to support a thriving global business community; and very few have local resources that would allow them to sustain a high standard of living."178 Because they will need to generate revenue to assist in the transition to a legitimate economic system, some form of revenue must be assigned to them in any agreement.

This Note proposes that home jurisdictions share with a tax haven a percentage of the revenue generated by their exchange of information with that tax haven. The revenue sharing could operate much like the EU withholding tax, albeit inversely. Rather than sharing a lower percentage of revenue in the beginning and moving upward during a transitional period, ${ }^{179}$ home jurisdictions should begin by sharing a high percentage of revenue and move downward. For example, revenue sharing could be $35 \%$ for the first three years, $20 \%$ for the subsequent three years, and $15 \%$ thereafter. ${ }^{180}$ The shared revenue would represent tax to the home jurisdiction and would otherwise go uncollected. This "tax" could help the tax haven develop a legitimate economy, and as a result, its dependence on the revenue sharing would wane until the transitional period ultimately expired. The concept is similar to purchasing information in order to impose tax. Under a purchasing scheme, home jurisdictions would bargain with tax havens for the right to receive information

172. See id.

173. See Savings Directive, supra note 119, art 11.

174. See supra notes $148-55$ and accompanying text.

175. Savings Directive, supra note 119 , art. 12, para. 1.

176. See generally EDWARDS \& MITCHELL, supra note 130, at 186-87.

177. See Savings Directive, supra note 119, art. 12, para.. 1.

178. PALAN ET AL., supra note 3 , at 3.

179. Savings Directive, supra note 119 , art. 11 , para. 1.

180. This example is purely illustrative and intended to mirror the EU Savings Directive's withholding tax. Serious consideration would be needed to determine what percentage of revenue to share, and into the length of the transition period. 
regarding their taxpayers' income. ${ }^{181}$

Sharing the tax revenue generated in the home jurisdiction might be a lengthy and inefficient process, but it would solve many of the difficulties associated with purchasing tax information. ${ }^{182}$ Instead of bargaining, setting the compensation for information at a percentage of newly generated tax revenue assures all parties that their compensation will be commensurate with their contribution. Tax havens currently sheltering the most assets would receive the most compensation, while those not currently sheltering assets would be prevented from holding out in an attempt to secure better payment for their information. Moreover, since the revenue sharing would decrease over the course of the transitional period, holdouts would stand to lose potential compensation by choosing not to cooperate with the initiative.

A multilateral revenue sharing arrangement would also prevent the potential hold-out problem that could arise from negotiating bilateral tax information purchases. ${ }^{183}$ In these negotiations, purchasing the needed tax information would become progressively more expensive as more tax havens sold information, ${ }^{184}$ and any tax havens refusing to sell would receive an influx of assets from individuals seeking information secrecy. ${ }^{185}$ Consequently, negotiating each successive purchase of information would become increasingly expensive until the information is unaffordable and the process stalls. $^{186}$

\section{CHANGING SECRECY LAWS}

The proposed tax information exchange standard will only be effective to the extent that a taxing authority possesses the information sought. In order for the taxing authority to access the information, countries must change their laws and administrative practices so that exchanging information for tax purposes is allowed. ${ }^{187}$ "The changes to internal laws may be very significant and may depend on political approval ...."

Critics commonly argue that changing secrecy laws constitutes an invasion of privacy. ${ }^{189}$ Such arguments, however, are disingenuous because the

181. Steven A. Dean, The Incomplete Global Market for Tax Information, 49 B.C. L. REV. 605,659 (2008).

182. See id.

183. Id.

184. Dean, supra note 94 , at 958.

185. Id.

186. Id.

187. Tax Justice Network, supra note 109, sec. 4.3.

188. Id.

189. See Daniel J. Mitchell, An OECD Proposal to Eliminate Tax Competition Would Mean Higher Taxes and Less Privacy, 21 TAX NoTES INT'L 1799, 1813 (2000) (arguing that "Financial privacy historically has been viewed as an essential safeguard of the citizen against the power of dictatorship."). 
information is only shared by states to which taxpayers have availed themselves, and the information being shared is only that to which respective governments rightfully have access to. ${ }^{190}$

Antagonists also argue that privacy plays an important role in sheltering the assets of individuals under oppressive governments. ${ }^{191}$ In fact, the Swiss "point to Nazi efforts to identify and seize Jewish assets in Swiss banks as the original basis for their financial secrecy statutes . . ."192 While such an argument may sound theoretically convincing, in reality, the primary motivation for holding assets in tax havens is not likely linked to the fear of their seizure by an oppressive government. Rather, it is the fear of a government taxing the earnings the assets generate. However, the inverse scenario, oppressive governments sheltering assets from their citizens, should be of greater concern.

\section{A. The Middle East: A Cautionary Tale}

Sovereign wealth funds "are actively managed, state-owned, and statecontrolled investment funds." "193 They represent an alternative to "investing additional dollars domestically in infrastructure or distributing money to citizens," and "some developing countries ... [use them] to amass resources, achieve higher financial returns, and gain a foothold in global capital markets." ${ }^{, 194}$ In 2008 , the countries controlling the largest sovereign wealth funds included Abu Dhabi, Saudi Arabia, and Kuwait. ${ }^{195}$ The Abu Dhabi fund alone is valued at $\$ 875$ billion. ${ }^{196}$

Given the amount of wealth Middle Eastern governments are sheltering from their citizens in sovereign wealth funds, civil unrest in that region highlights the potential harm secrecy laws present to the international community and provides an opportunity to generate support for their change. Beginning in December 2010, "mass protests . . brought down [Tunisian] President Zine El Abidine Bin Ali[,] . . . toppled autocratic Egyptian President Hosni Mubarak, launched an armed rebellion against Libyan despot Moammar

190. Residents choosing to maintain citizenship in their host nation are implicitly authorizing their host nation to tax them accordingly. See supra notes $72-73$ and accompanying text.

191. Id.; See also Mitchell, supra note 189, at 1813.

192. Ethan A. Nadelmann, Unlaundering Dirty Money Abroad: U.S. Foreign Policy and Financial Secrecy Jurisdictions, 18 U. MIAMI INTER-AM. L. REV. 33, 61 (1986).

193. Michael S. Knoll, Taxation and the Competitiveness of Sovereign Wealth Funds: Do Taxes Encourage Sovereign Wealth Funds to Invest in the United States?, 82 S. CAL. L. REV. 703, $706(2009)$.

194. Victor Fleischer, $A$ Theory of Taxing Sovereign Wealth, 84 N.Y.U. L. REV. 440, 454

195. Knoll, supra note 193, at 707.

196. Id. 
Gadhafi, and rattled governments in Yemen, Bahrain and elsewhere."197 Amongst the embattled countries were regimes such as Libya's, which control a sovereign wealth fund valued at over $\$ 50$ billion. ${ }^{198}$ Other oil-rich monarchies tried to preempt protests by offering to distribute money to citizens. ${ }^{199}$ Saudi Arabia offered social benefits for civil servants, a fifteen percent pay raise for state employees, and an increase in funds for housing loans; Bahrain offered a thirty percent reduction in the mortgage costs of 30,000 households; Oman offered a monthly allowance of $\$ 390$ for each registered job seeker and gave orders to provide 50,000 new jobs; and Kuwait offered 1,100,000 citizens $\$ 3,570$, free distribution of basic food items for fourteen months, and a $115 \%$ pay raise for servicemen. ${ }^{200}$

In the event of civil uprisings in these countries, newly installed democratic governments should be entitled to control of their country's respective sovereign wealth fund. However, tax havens and their secrecy laws present a significant obstacle to locating and gaining control of such funds. Even sovereign wealth funds that "are legally independent from the governments that own them ... are not practically independent. When pressed, the managers of such funds are likely to act as their home country government wants them to act." ${ }^{201}$ Should the leaders of Arab nations feel they are on the verge of being ousted, they could pressure the managers to transfer assets into tax havens with bank secrecy laws. Thereafter, the leaders could siphon assets from the fund and keep them within secrecy jurisdictions. This would ensure the leader would retain great wealth after being removed from power.

What is more, a significant percentage of Middle Eastern assets are already held in secrecy jurisdictions, increasing the likelihood that assets could be siphoned and making the siphoning process easier. ${ }^{202}$ In their Global Wealth Report for 2003, Boston Consulting Group estimated that the Middle East and Asia had \$10.2 trillion in total wealth, \$4.1 trillion of which is probably held offshore. ${ }^{203}$ This estimate was the highest monetary amount and the second highest percentage of total wealth of any continent's offshore holdings. ${ }^{204}$ These

197. Karin Laub, In Birthplace of Arab Uprising, Discontent Lingers, WASH. POST (Mar. 12, 2011), http://www.washingtonpost.com/wp-dyn/content/article/2011/03/12/ AR201 1031201289.html. While armed rebels fought for control of Libya, a separate battle for control of Libya's sovereign wealth fund was also underway. Landon Thomas Jr., Libya's Hidden Wealth May Be Next Battle, N.Y. TiMES, Mar. 4, 2011, at B1.

198. Fleischer, supra note 194.

199. Jacques Charmelot, Oil-Rich Arab States Open Their Coffers, AgenCE FranCePRESSE, Feb. 27, 2011.

200. Id.

201. Knoll, supra note 193, at 708.

202. Murphy, supra note 50.

203. Id.

204. It was estimated that North America had total wealth of $\$ 16.2$ trillion, $\$ 1.6$ trillion of which was probably held offshore, or about ten percent of total wealth; Europe was estimated to have total wealth of $\$ 10.3$ trillion, $\$ 2.6$ trillion of which was probably held offshore, or about 
assets rightfully belong to the citizens of the sovereign nations, and the inability to access them may serve as a catalyst for secrecy law reform.

\section{B. Ireland: The Face of the Initiative}

In order for the OECD to generate the political prowess necessary to change tax havens' internal secrecy laws, it will need to strategically select a country to serve as the "face" of the initiative. Because OECD initiatives typically suffer from the perception that Member States are favored at the expense of tax haven, ${ }^{205}$ the organization struggles with an image of representing the "big guys against the little guys." ${ }^{, 206}$ Inevitably, a new initiative will need "to achieve consensus within a diverse group [of] . . countries,"207 and Ireland may provide the best opportunity for leadership. Ireland is a country to which tax havens can relate and behind which they can rally.

In February 2007, Ireland "was one of the wealthiest countries in Europe, with a booming construction industry, an average per capita income of $€ 200,000(\$ 270,000)$ and economic growth of $6 \%$ per year." ${ }^{208}$ By February 2011 , Ireland was "in a state of financial ruin, struggling under $€ 95$ billion ( $\$ 130$ billion) of debt, spiraling unemployment and a crippled housing market." ${ }^{209}$ A coalition government led by Enda Kenny of the Fine Gael party gained control in parliament after the February 2011 national elections. ${ }^{210}$ The coalition's 113-seat parliamentary majority is the largest majority in Ireland's history. ${ }^{211}$ Prime Minister Kenny "vowed to solve a bank-bailout crisis that overwhelmed Ireland's finances and required an emergency rescue by the European Union and International Monetary Fund," saying, "terms of the EUIMF loans must be renegotiated to make them more affordable for Ireland and enable that country's recovery from deficits and double-digit unemployment.",212

In November 2010, Ireland agreed to borrow $€ 85$ billion from Member States of the EU through the European Financial Stability Fund, bilateral loans from the United Kingdom, Sweden, and Denmark, and the International

twenty-five percent of total wealth; Latin America had total wealth of $\$ 1.3$ trillion, $\$ 700$ billion of which was probably held offshore, or about fifty-four percent of total wealth; the report estimated that $\$ 9$ trillion in total was probably held offshore, roughly $23.7 \%$ of total wealth. Id.

205. SHARMAN, supra note 12 , at 2.

206. See PALAN ET AL., supra note 3, at 213.

207. Avi-Yonah, supra note 78, at 1662.

208. Genevieve Carbery, All Change as Ireland Goes to the Polls, Time (Feb. 25, 2011), http://www.time.com/time/world/article/0,8599,2053605,00.html.

209. Id.

210. Shawn Pogatchnik, Enda Kenny Elected Ireland's Premier, WASH. Post (Mar. 9, 2011), http://www.washingtonpost.com/wp-dyn/content/article/2011/03/09/ AR2011030900799.html.

211. Id.

212. Id. 
Monetary Fund. ${ }^{213}$ Ireland itself contributed $€ 17.5$ billion of the funds from their National Pension Reserve Fund, decreasing the amount of external assistance to $€ 67.5$ billion. ${ }^{214}$ The borrowing was necessitated by the "high yields on Irish bonds," which "curtailed [Ireland's] ability to borrow. Without [the] external support, [Ireland] would not be able to raise the funds required to pay for key public services for [Irish] citizens ... [ [or] provide a functioning banking system to support economic activity." ${ }^{215}$ As a condition to lending the money, Ireland had to comply with EU mandates. ${ }^{216}$ "The [2011] budget implement[ed] the first stage of the four-year National Recovery Plan .... It [sought] to trim $€ 15$ billion from Ireland's deficit to bring it under the EUmandated level of 3 percent of GDP in 2014." ${ }^{, 217}$ The National Recovery Plan "call[ed] for two-thirds of deficit reductions to come from spending cuts, with one-third to come from tax increases." 218 Under the National Recovery Plan, Ireland's corporate tax rate of $12.5 \%$ remained unchanged. ${ }^{219}$

Many Member States of the EU are unhappy with the fact that they are lending money to Ireland while its corporate tax rate remains unchanged, feeling as if they are subsidizing their competition. ${ }^{220}$ After all, Ireland set the trend of tax competition in Europe "by resisting the EU pressure for tax harmonization and enacting a $12.5 \%$ corporate tax rate., 221

The EU charge against Ireland's $12.5 \%$ corporate tax rate is led by France and Germany. ${ }^{222}$ These nations have called "for a common consolidated corporate tax base (CCCTB), which would allow companies to use a single tax regime instead of the [EU's] 27 different corporate tax systems." 223 Prime Minister Kenny, however, has "made it perfectly clear" that "the corporation tax and the consolidated tax base are of absolute fundamental importance to Ireland and that [the country] could not concede any movement on [them].,224 The proposition would not only undermine the competitiveness of Ireland's corporate tax base, but it would be an affront to popular opinion in Ireland,

213. Government Statement, Gov't of Ir., Dep't of Fin., Announcement of Joint EU - IMF Programme for Ireland (Nov. 28, 2010), available at http://www.finance.gov.ie/ viewdoc.asp?DocID $=6600$.

214. Id.

215. Id.

216. Id.

217. David D. Stewart, Lenihan Announces Austere 2011 Budget, 57 TAX NOTES INT'L $838,838(2010)$.

218. Id.

219. Id.

220. See Stephanie Berrong, Irish Opposition Leader Responds to Proposed Eurozone Tax Reforms, 61 TAX NOTES INT'L 564, 564 (2011).

221. Pastukhov, supra note 131, at 165-55.

222. Berrong, supra note 220 , at 564 .

223. Id.

224. Id. 
which supports respecting national sovereignty on taxation. ${ }^{225}$

Ireland is noteworthy because it is a country with low corporate tax rates and is desperately in need of increased tax revenues. Residents of Ireland, which imposes a top personal income tax rate of $41 \%,{ }^{226}$ do not enjoy the same low tax rates as Irish corporations:

As Europe's major economies focus on belt-tightening, they are following the path of Ireland. But the once thriving nation is struggling, with no sign of a rapid turnaround in sight. ... [A]n economic collapse forced Ireland to cut public spending and raise taxes, the type of austerity measures that financial markets are now pressing on most advanced industrial nations. ... Politicians [in Ireland] have raised taxes and cut salaries for nurses, professors and other public workers by up to $20[\%]$... . [Ireland] lured knowledge-based multinationals ... with a $12.5[\%]$ tax rate, giving Ireland one of the most exportdependent economies in the world. Now, the government is pinning nearly all its hopes on an export revival to lift the economy. . . . Many voters, having experienced the pain of austerity, are expected to express their anger in ... [future] elections. ${ }^{227}$

As a country whose population is feeling the weight of tax burdens on an individual level, Ireland represents the type of political environment that presents an opportunity for those seeking the eradication of harmful preferential tax practices. While Ireland remains committed to retaining its sovereignty by maintaining its corporate tax rate, the EU's bailout of Ireland pressures the country to comply with EU mandates. Having been swept into power by the Irish people, Prime Minister Kenny has the political capital to lead the international effort against tax havens. If he hopes to keep solutions outside the realm of setting tax floors, Prime Minister Kenny should consider spearheading the campaign for multilateral, automatic exchange of tax information.

\section{Conclusion}

With countries throughout the world implementing austerity measures in the wake of the worldwide financial crisis and credit crunch, a window of

225. See Charles Gnaedinger, Irish Voters Approve Lisbon Treaty, 56 TAX NOTES INT'L 96, 96-97 (2009).

226. EUROPEAN COMM'N, supra note 148, at 8, Graph 3. Ireland's top personal income tax rate is above the average European Union country's top personal income tax rate of $37.5 \%$. See id.

227. Liz Alderman, In Ireland, a Picture of the High Cost of Austerity, N.Y. TIMEs (June 28, 2010), http://www.nytimes.com/2010/06/29/business/global/29austerity.html?_I=1. 
political opportunity has been opened through which international bodies such as the OECD can and should implement a new, truly multilateral agreement that facilitates the automatic exchange of tax information. This standard agreement should inclusively define its terms so that it requires automatic information exchange. ${ }^{228}$ In order to aid in the legitimization of tax haven economies, the agreement should also require revenue sharing among its parties, and the revenue shared should represent a percentage of tax revenue realized as a result of tax information exchange. ${ }^{229}$

Prior to implementation, the bank secrecy laws of participating countries must be changed so that they can efficiently access each other's relevant tax information. ${ }^{230}$ The unrest in the Middle East provides an opportunity to generate popular support for these changes. ${ }^{231}$ In order to accomplish the politically difficult task of changing secrecy laws, countries such as Ireland will need to reach out to similarly situated countries throughout the world and articulate why reform is needed ${ }^{232}$ Ireland traditionally has lower tax rates but is badly in need of tax revenues, and in light of the increased political pressure international governing bodies have been able to place on Ireland for receiving bailouts during the financial crisis, the country should be eager to move the debate away from setting tax floors and to re-focus it on automatically exchanging tax information. ${ }^{233}$ The increased revenue received from revenue sharing would be a much-needed stimulus in the interim, while allowing sovereign nations to retain their right to set and define tax rates in the future. Sovereign nations with low tax rates are not the problem; lack of transparency is the problem. The solution is effective exchange of information.

228. See supra notes 169-72 and accompanying text.

229. See supra notes $179-81$ and accompanying text.

230. See supra notes $187-88$ and accompanying text.

231. See supra Part V.A.

232. See supra Part V.B.

233. See supra notes 222-23 and accompanying text. 
